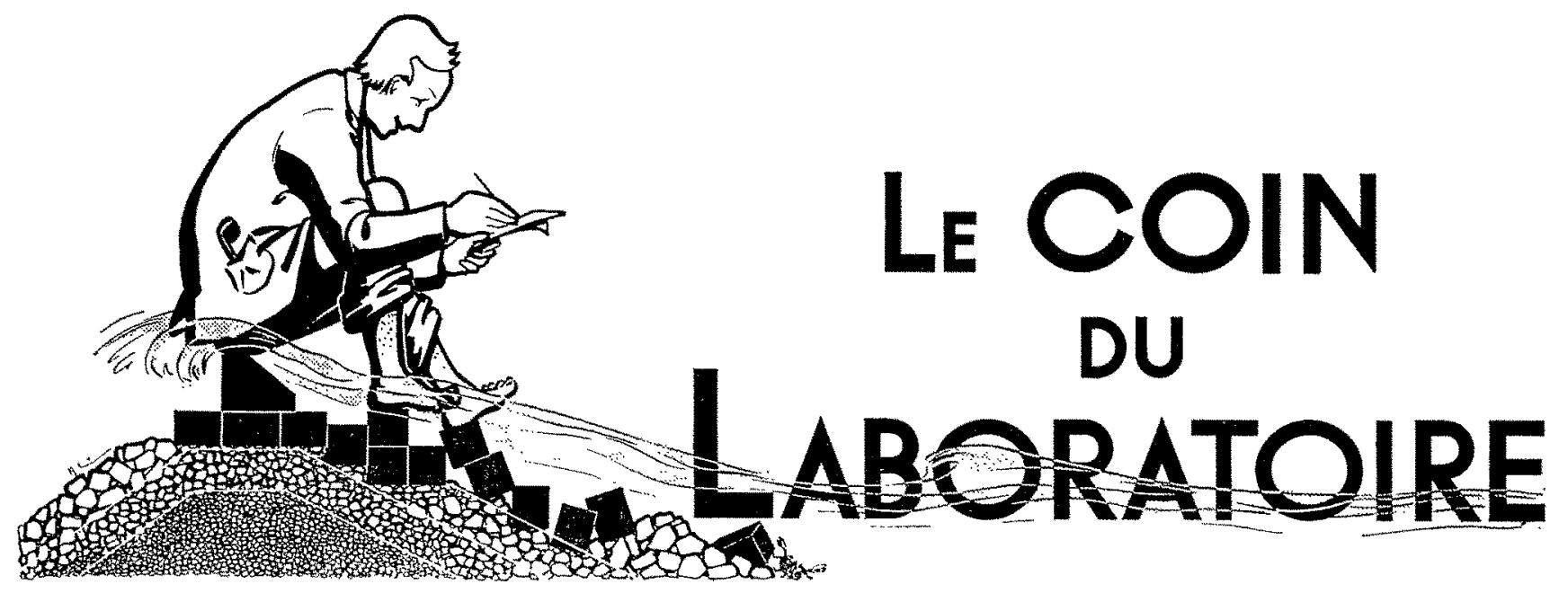

\title{
Deux solutions de micromanomètre
}

\author{
English text, p. 182
}

\begin{abstract}
Deseription d'un micromanomètre réalisable à partir d'éléments couramment utilisés dans les laboratoires: deux tubes en $U$, et un tube capillaire dans lequel une bulle d'air se déplace sous l'action des pressions. Possibilité d'aménager l'appareil aussi bien pour la mesure des pressions de gaz que ponr la mesure des pressions d'ean (jusqu'à $0,01 \mathrm{~mm}$ ). Présenlation d'un second appareil permettant de mesurer de faibles dénivellations de liquides el, en conséquenee, des pressions de gaz. Appareil essentiellement constitué d'un flotteur, tont les mouvements verticaux sont transmis d tu niveau géodésique (sensibilité obtenue: $1 \mathrm{mi-}$ (ron). A noter: les supports sphériques, qui assurent la constance de la charge sur le flottenr pendant les déplacements de la bulle d'air.
\end{abstract}

La mesure des faibles pressions d'eau ou d'air est très fréquente dans les laboratoires d'hydraulique, soit que l'on veuille étudier la répartition des pressions autour d'un corps immergé, soit que l'on emploie le tube de Piтot pour la mesure des vitesses. C'est ainsi par exemple que la mesure des vitesses sur modèles réduits peut entrấner la détection de très faibles écarts de pression. Il nous paraît inutile d'insister sur les avanta-

\begin{abstract}
Description of a micromanometer constructed from ordinary laboratory equipment, i.e. two $U$ tubes and a capillary tube in which an air bubble moves under the action of pressure. Possibility of using the apparatus with equal efficiency for measurements of both gas and water pressures (up to $0.01 \mathrm{~mm}$ ). Presentation of a second apparalas enabling measurement of small drops in level of liquids and consequently also of gas pressures. The instrument mainly comprises a float, the bertictl movements of which are transmitied to a geodetic level (sensitivily: 1 micron). Nole the spherical supports which ensure a constant load on the float while the air bubble is in molion.
\end{abstract}


Une telle amplification ne peut évidemment guère être considérée comme suffisante lorsque les pressions à mesurer sont de l'ordre de $0,1 \mathrm{~mm}$; ceci d'autant plus que le ménisque au contact des deux liquides est très difficile à repérer exactement en raison de l'instabilité de sa forme.

Quelques expériences peu encourageantes, réalisées avec des manomètres à deux liquides de construction usuelle, nous ont conduits ì rechercher de solutions nouvelles.

\section{1}

\section{Principes}

Une première solution est basée sur une idée de M. R. Mour [1] que nous exposons brièvement ci-après.

Un vase de diamèle $D$ est solidaire d'un tube fin de diamètre $d$ (fig. 1). Le vase est rempli de

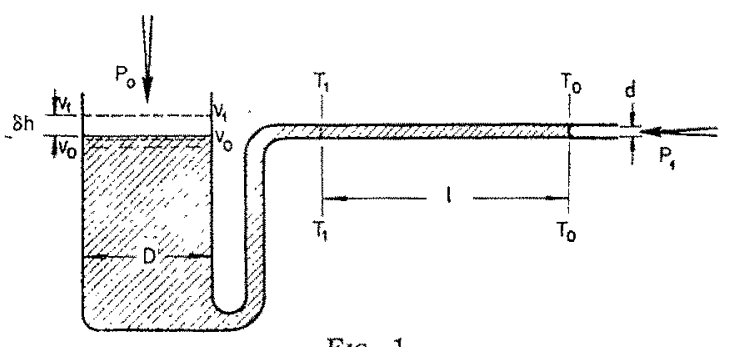

Fig. 1

liquide jusqu'au niveau $\mathrm{V}_{0}-\mathrm{V}_{0}$. Le ménisque dans le tube a alors une position d'équilibre $\mathrm{T}_{0}-\mathrm{T}_{0}$. Une pression $p_{1}>p_{0}$ se traduira par un déplacement $l$ du ménisque et par une ćlévation $\delta h$ du niveau dans le vase. Le nouvel état d'équilibre sera atteint lorsque $p_{1}-p_{0}=\varpi \delta h$. De l'égalité des volumes du liquide déplacés dans le tube et dans le vase on tire :

et :

$$
l=\delta \hat{o} h .(\mathrm{D} / d)^{2}
$$

ou :

$$
p_{1}-p_{0}=\Phi \cdot l .(d / \mathrm{D})^{2}
$$

$$
l=\left[\left(p_{1}-p_{0}\right) / \bar{\omega}\right](\mathrm{D} / d)^{2}
$$

Nous désignerons désormais par A le coefficient d'amplification, soit $A=(1 / \bar{\omega})(D / d)^{2}$.

En faisant varier $D$ et $d$ on peut obtenir des coefficients d'amplification lonjours adaptés ì l'échelle des pressions à mesurer.

Sous cette forme très schématique, un tel manomètre ne semble guère exploitable; un tube absolument horizontal correspond à un point de vue exclusivement théorique. De plus, dans un tube horizontal, le ménisque peut revêtir des formes très diverses qui dépendent, si l'on en croit l'expérience, du diamètre du tube et de la nature du liquide employé. La figure 2 montre trois formes de ménisque observées pratiquement. Seule la forme $(\alpha)$ peut être considérée comme satisfaisante pour les mesures. Nous pensons
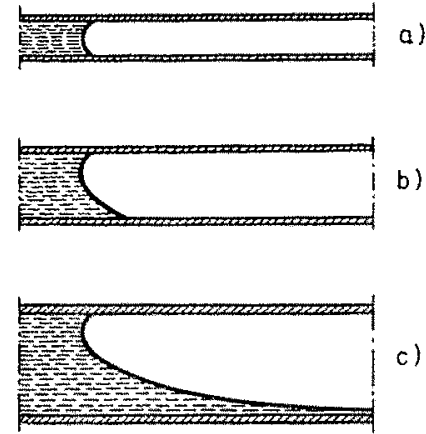

FIG. 2

que le diamètre maximum permettant d'obtenir la forme considérée peut être calculé d'après la formule de LAPLACE relative à la tension superficielle (fig. 3) :

$$
T=\sigma\left(1 / R_{1}+1 / R_{2}\right)
$$

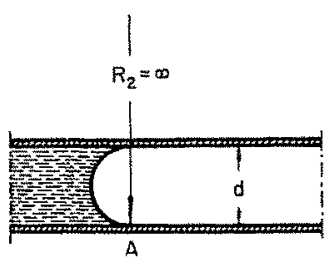

Fif. 3

Dans un tube horizontal, la pression hydrostatique au point (A) ne doit pas dépasser la tension superficielle, si l'on veut obtenir un ménisque de la forme $(a)$. Il en résulte :

$$
d \cdot \overline{\bar{\omega}}=\sigma\left(1 / \mathrm{R}_{1}+1 / \mathrm{R}_{2}\right)
$$

et avec $\mathrm{R}_{1}=d / 2$ el $\mathrm{R}_{2}=\infty$ :

$$
d=\sqrt{\frac{2 \sigma}{\pi}}
$$

Pour l'eau, on a :

$$
\sigma=0,0745 \mathrm{~g} / \mathrm{cm}^{2} \quad \text { et } \bar{\omega}=1 \mathrm{~g} / \mathrm{cm}^{3}
$$

d'où :

$$
d=0,386 \mathrm{~cm}
$$

Pour le tétrachlorure de carbone, on a :

d'où :

$$
\sigma=0,0273 \mathrm{~g} / \mathrm{cm} ; \bar{\omega}=1,6 \mathrm{~g} / \mathrm{cm}^{*}
$$

$$
d=0,185 \mathrm{~cm}
$$

Les résultats obtenus par l'équation (3) se trouvent en accord avec ceux qui ont pu être observés. 
Pour surmonter les dilficultés dues à l'horizontalité du tube capillaire, nous avons procédé de la manière suivante:

- Deux vases de même section sont reliés par un tube capillaire de diamètre $d$ et sont remplis partiellement d'eau (fig. 4). Quelques gouttes d'un

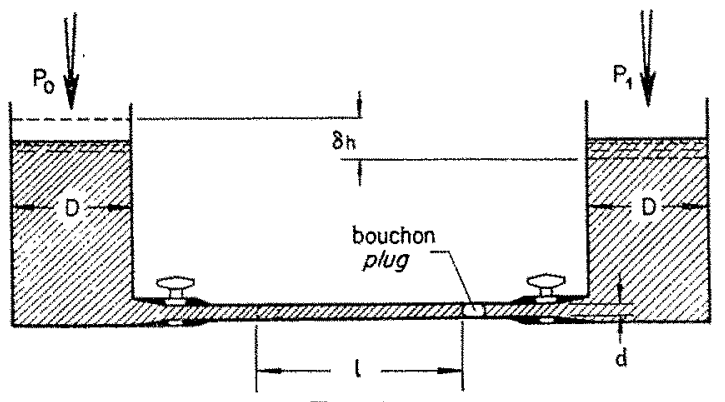

Fig. 4.

liquide (aniline) non soluble dans l'eau forment un $\&$ bouchon $\$$ se déplaçant dans le tube sous l'action des pressions appliquées. Dans ce cas, la distance entre les deux positions du ménisque est :

$$
l=(\delta h / 2)(\mathrm{D} / d)^{2}
$$

et la différence des pressions :

$$
p_{1}-p_{0}=\bar{\omega} .2 l /(\mathrm{D} / d)^{2}
$$

le coefficient d'amplification ayant pour valeur :

$$
\mathrm{A}=(1 / 2 \pi)(\mathrm{D} / d)^{2}
$$

Le fonctionnement de ce dispositif ne s'avère pas satisfaisant. En raison de la solubilité, pourtant très faible, de l'aniline $(\omega=1,02)$ dans l'eau, le bouchon disparait au bout de quelques jours. Mais l'inconvénient le plus grave, compromettant la précision de l'instrument, est la déformation que subit le bouchon par suite de l'adhésion de l'aniline à la paroi mouillée du tube. C'est ainsi que l'on en vint à remplacer le bouchon d'aniline par une bulle d'air. Celle-ci peut, elle aussi, constituer un bouchon interdisant toute communication entre les deux vases à condition que sa longueur soit au minimum de $3 d$ et à condition que le diamètre du tube ne dépasse pas la valeur limite résultant de l'équation (3).

Evidemment, avec un bouchon dont la densilé serait sensiblement celle du liquide employé, la position du tube capillaire n'aurait aucune influence sur le fonctionnement de l'appareil. Un bouchon d'air tend, au contraire, à s'élever. L'emploi du bouchon d'air exige donc que le lube, reliant les deux vases, soit sensiblement horizontal. L'expérience nous a montré cependant qu'avec un tube dont le diamètre satisfait a l'équation (3) on pouvait travailler sans se préoccuper de son horizontalité.
L'insufflation de la bulle d'air dans le tube capillaire peut être menée à bien selon divers procedés; le plus commode nous semble le suivant :

L'appareil ayant été rempli de liquide, et ses robinets fermés, on le place sur un plan légèrement incliné. Puis, à l'aide d'une pipette et d'un lube flexible, on insuffle une petite quantite d'air de façon que la bulle se place tout près du cône du robinet inférieur. En appliquant alors une pression convenable au vase inférieur et en ouvrant lentement les robinets, la bulle d'air glisse dans le tube.

Ce manonètre ne pourrait être ulilise que pour les mesures de pression des gaz. Le liquide de remplissage à préférer est l'alcool; l'emploi de l'eau, même distillée, est à déconseiller car

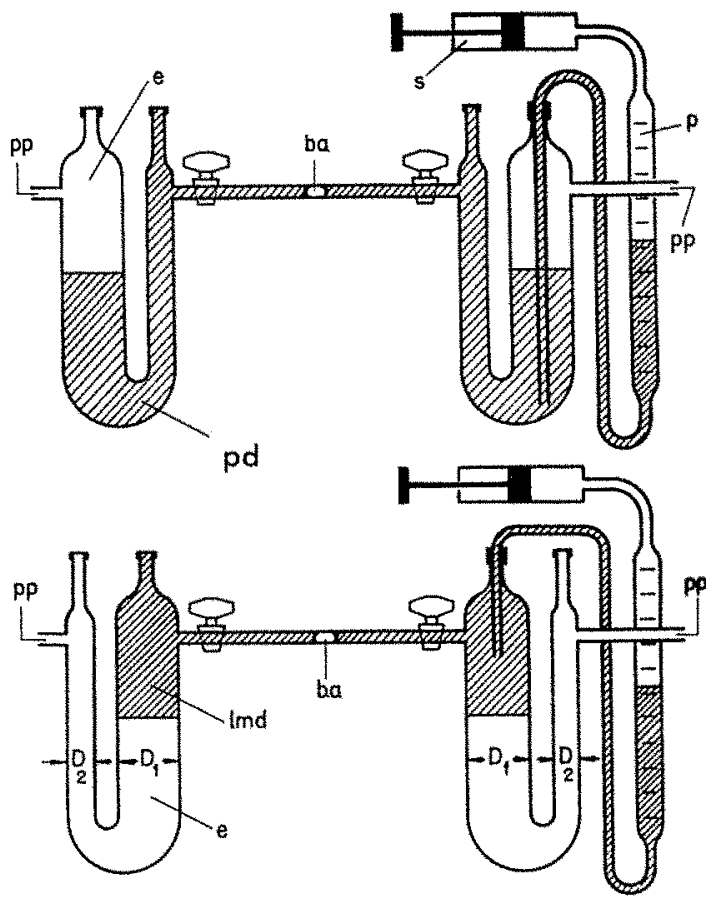

Fia. 5. - (ba) bulle d'ail, (c) eau, (Ipd) liquide plus dense que l'eau, (lmd) liquide moins dense que l'eau, (p) pipelte, (pp) prise de pression, (s) seringue.

(ba) air bubble, (o) water, (lpd) liquid more dense than ibater, (1md) liquid less dense than water, (p) pipette, (pp) pressure intake, (s) syringe.

il est très difficile d'obtenir un glissement parlait de la bulle dans le tube. En tout cas, un nettoyage soigneux du tube capillaire avant l'usage est indispensable.

On peut, sur le même principe, réaliser un manomètre convenant à la mesure des pressions d'eau. On peut inême, dans ce cas, obtenir un coefficient d'amplification global très élevé en réalisant la superposition du rapport $(\mathrm{D} / d)^{2}$ el du facteur $A=\Phi_{c} /\left(\bar{\omega}_{t}-\Phi_{l}\right)$ valable pour les ma nomètres à deux liquides; c'est une solution de ce genre que présente la figure 5. 
Deux tubes en U sonl reliés entre eux par un tube fin et remplis d'un liquide, soit plus dense soit plus léger que l'eau, suivant la disposition indiquée par les figures. On voit immédiatement que le coefficient d'amplification devient :

$$
A=1 / 2 \bar{\omega}_{c}(D / d)^{2} \cdot \frac{\bar{\omega}_{e}}{\bar{\omega}_{0}-\bar{\omega}_{l}}
$$

Pour se réserver la possibilité de faire varier le rapport $\mathrm{D} / d$, on peut réaliser des tubes en $\mathrm{U}$ ayant des branches de diamitres différents.

\section{Gamme, précision et sensibilité de l'appareil}

Par suite de la possibilité d'obtenir des coefficients d'amplification considérables, on est naturellement tenté de choisir des rapports $\mathrm{D} / d$ élevés. Mais l'adoption de valeurs élevées de ce rapport ne va pas sans inconvénients. Ainsi, en adoptant un rapport $\mathrm{D} / d$ très grand, on limite considérablement la gamme des mesures, à moins de consentir à des longueurs de tube vraiment excessives. En outre, la bulle d'air n'atteint sa position d'équilibre que très lentement. Heureusement, toutes ces difficultés peuvent être surmontées si l'on s'applique à tenir la bulle à sa position zéro, soit par l'emploi d'une vis micrométrique relevant ou abaissant l'un des vases (un tube en $\mathbf{U}$ ) dans le sens indiqué par la différence des pressions, soit par prélèvement, ou addition, d'une certaine quantité de liquide facile à déterminer. Il semble que la dernière méthode soit plus simple et plus précise : elle évite l'emploi d'une vis micrométrique spéciale et celui du tube flexible qui relie le tube capillaire et le vase mobile et dont les déformations pourraient fausser les mesures. La deuxième méthode n'exige en effet qu'une seringue et une pipette calibrée; pratiquement elle est, de plus, très rapide. Les deux méthodes sont également applicables aux manomètres à deux liquides. Il est à peine besoin de préciser que, pour une même différence de pression, un liquide plus dense que l'eau exige une surélévation du twbe en $U$ mobile, là où un liquide moins dense exigerait son abaissement.

En ce qui concerne la fidélité et la sensibilité de ces types d'appareils, les quelques résultats donnés ci-dessous permettront de fixer les idées :

\section{a) MANOMİTRE A ALCOOL :}

$A=604 \pm 1,35 \%$,

Déplacement de la bulle décelable pour une différence de pression $\delta h=0,0025 \mathrm{~mm}$ d'alcool. b) MANOMÈTRE a ALCOOL :

$$
\mathrm{A}=45 \pm 0,28 \%,
$$

Déplacement décelable pour $\delta ~ h=0,01 \mathrm{~mm}$.

c) Manomètre a deux Liquides (tétrachlorure de carbone-eau):

$\mathrm{A}=26,8 \pm 1,18 \%$,

Déplacement décelable pour $\delta h=0,01 \mathrm{~mm}$ d'eau.

De nombreuses mesures ont maintenant étí effectuées, qui confirment l'intérêt pratique de ces appareils.

\section{II}

La réalisation dont il sera question maintenant ne peut être utilisée que pour mesurer des pressions de gaz, appliquées à deux surfaces d'eau. Les mouvements verticaux de l'une des surfaces sont transmis, par l'intermédiaire d'un flotteur, à un niveau de précision géodésique.

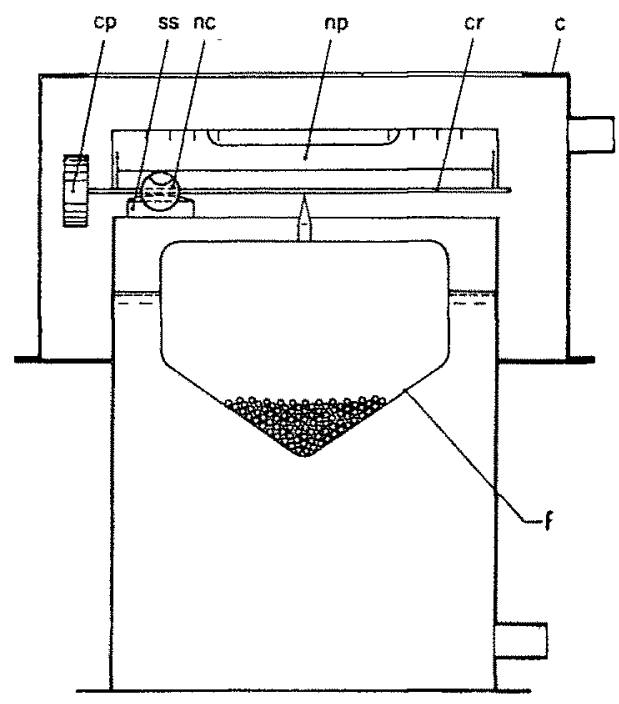

FiG. 6. - (c) couvercle, (ci) croix métallique, (cp) contrepoids, (nc) niveau de contrôle, (np) niveau principal, (ss) support sphérique, (f) flotteur.

(c) cover, (cr) metal cross, (cp) counterweighl, (11e) control geodetic level, (np) measure geodetic level, (ss) spherical support, (f) float.

Les appareils à flotteurs peuvent faire preuve d'une sensibilité exceptionnelle, comme J'ont démontré M. Spalding avec son manomètre [2] et M. Hrcrox avec son évaporimètre [3].

Nous donnons ci-après, illustrées par la figure 6 , quelques brèves indications concernant notre réalisation. 
Un flotteur d'aluminium de $80 \mathrm{~mm}$ de diamètre est placé dans un pot métallique de $113 \mathrm{~mm}$ de diamètre. Un pointeau, disposé à sa partie supérieure, agit sur l'une des branches d'un croisillon métallique qui repose par ailleurs sur deux couteaux fixés au rebord du pot. Le croisillon porte deux niveaux géodésiques; l'un dans le plan vertical des deux couteaux permet de contrôler l'horizontalité des supports, l'autre, l'essentiel, est un niveau de précision placé sur l'autre branche du croisillon, dans une direction perpendiculaire. La bulle de ce dernier niveau se déplace suivant les mouvements verticaux $d u$ flotteur.

Si l'on utilise un niveau de haute précision, il semble possible de mesurer des dénivellations extrêmement faibles.

Les niveaux usuels n'ayant qu'une longueur très limitée, on pourrait, pour étendre leur gamme d'utilisation, appliquer les méthodes mentionnées dans le chapitre précédent.

Le coefficient d'amplification de l'appareil ne dépend que de la qualité du niveau géodésique et de la longueur du bras de levier $l$. Ainsi, pour s'assurer un coefficient d'amplification $A=500$ avec un niveau variant de $2 \mathrm{~mm}$ pour $20^{\prime \prime}$, la longueur du levier doit être :

$$
l=2 / 500.206265 / 20=41,25 \mathrm{~mm}
$$

Sur le premier appareil réalisé suivant ce principe, on constata avec surprise un coefficient

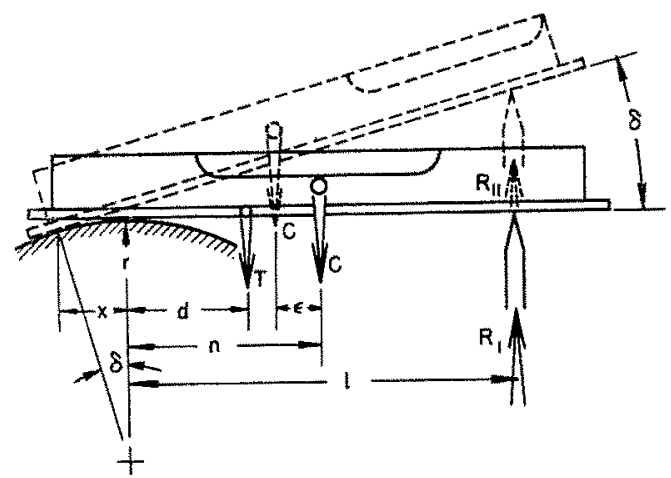

FIG. 7

d'amplification beaucoup plus élevé que prẻvu. Ceci était dû aux modifications de la charge supportée par le flotteur, ce qui provoquait des variations de son tirant d'eau. Nous avons réussi à tenir constante la charge sur le flotteur, en remplaçant les supports fixes triangulaires par des supports sphériques. Le rayon de courbure a été calculé de la manière suivante (fig, 7) : soit C... la charge "mobile », c'est-à-dire le poids du liquide du niveau, T... la charge statique, c'est-à-dire le poids du croisillon et de tout ce qu'il supporte, $\varepsilon . .$. le déplacement dụ centre de gravité,

dans la position I, la charge sur le flotteur s'évalue à :

$$
\mathrm{R}_{\mathrm{I}}=\frac{\mathrm{C} \cdot \boldsymbol{n}+\mathrm{T} \cdot d}{l}
$$

Après un déplacement de la bulle (position II), la nouvelle charge est :

$$
\mathrm{R}_{\mathrm{II}}=\frac{\mathrm{C}(n+x-\varepsilon)+\mathrm{T}(d+x)}{l+x}
$$

La condition $R_{I}=R_{I I}=$ constante exige que la longueur du levier $l$ augmente ou diminue suivant :

$$
x=\frac{\mathrm{C} \cdot l \cdot \varepsilon}{\mathrm{C}(l-n)+\mathrm{T}(l-d)}
$$

Si les charges sont équilibrées de facon que le flotteur ne supporte que le poids du liquide du niveau principal, on a :

$$
l=n \quad d=0 \quad \text { et } \quad x=\frac{\mathrm{C} \cdot \mathrm{E}}{\mathrm{T}}
$$

d'où le rayon de courbure :

$$
r=\left(x / \delta^{\prime \prime}\right) .206265
$$

En modifiant les supports dans ce sens, on a constaté un coefficient d'amplification de $466 \pm 1,2 \%$ correspondant à une valeur de $21,46^{\prime \prime}$ pour le niveau. La fidélité de l'appareil devenait excellente, ce qui n'était pas le cas tout d'abord. On pouvait observer sans diffeulté les déplacements de la bulle pour des dénivellations de l'ordre de $0,001 \mathrm{~mm}$. Nous n'avons pas juge nécessaire d'adopler des dispositifs spéciaux évitant au croisillon de glisser sur les supports sphériques.

Pour effectuer des mesures de pression, on recouvre le pot d'un couvercle transparent muni d'un ajutage pour la prise de pression et on met en communication le pot métallique avec un autre récipient.

\section{E. Kovacic,}

Ljubljana, Yougoslavie.

BIBIIOGRAPHIE

(1) R. Moнn. - Messgeraet von beliebiger Genauigkeit fuer kleine Laengenaenderungen. $Z$. fuer tech. Physik, 1932, p. 477.

[2] D. B. Spalding, - A simple manometer for use in measuring low air velocities. Journal Sci. Instr., 1950 , p. 310 .

[3] G. H. Hrckox. - Evaporation from a free water surface. Trans. Am. Soc. C. E., 1946, p. 1. 


\title{
LABORATORY PRACTICE
}

\section{Two solutions for micromanometer}

\author{
Texte francais, p. 177
}

See French text (p. 178) for illustrations

Low water or air pressures are measured very frequently in Hydraulic Laboratories, especially when one wishes to study pressure distribution round a submerged body or when a PITox tube is used to measure velocities. Thus it is that measurements of velocity on scale models may necessitate a recording of very slight differences in pressure. It is not necessary to emphasize the advantages of the Prror tube by comparing it to other instruments of the same kind. However, when it is used with low velocities of, say, $v<10 \mathrm{~cm}$ per second, particularly sensitive manometers are required. Manometers using two licuids are quite naturally prefered since they produce an amplification $\omega_{s} /\left(\bar{\omega}_{\theta}-\bar{\omega}_{t}\right)$ of about 7,5 if, for example, the sealing liquid is toluene.

It is obvious that such an amplification is hardly adequate when the pressures to be measured are about $0,1 \mathrm{~mm}$, particularly as the meniscus between the two fluids is very difficult to mark exactly because its shape does not remain stable.

A few unsatisfactory experiments with standard two fluid manometers has led us to seek new answers in the problem.

\section{I}

\section{BASIS OF CONSTRUCTION}

One solution, based on Mr. R. Momn's idea [1], is explained in the following paragraphs.

$A$ vessel of diameter $D$ is integral with a thin tube of diameter $d$ (fig. 1). The vessel is filled with liquid up to the level $V_{0}-V_{0}$ The meniscus in the tube is then levelled off at $\mathrm{T}_{0}-\mathrm{T}_{0}$. A pressure $p_{1}>p_{0}$ becomes apparent due to a movement $l$ of the meniscus and by an increase $\delta h$ of the level in the vessel. The new balance is reached when $p_{3}-p_{0}=\bar{\omega} . \delta \mathrm{h}$.

From the equal volumes displaced in the tube and the vessel :

$$
l=\delta h \cdot(\mathrm{D} / d)^{2}
$$

and :

or :

$$
p_{1}-p_{0}=\bar{\omega} \cdot l \cdot(d / \mathrm{D})^{2}
$$

$$
l=\left[\left(p_{1}-p_{0}\right) / \bar{\omega}\right](\mathrm{D} / d)^{2}
$$

The coefficient of amplification will now simply be denoted by $A$; thus $A=(1 / \omega)(D / d)^{2}$.

By varying both $D$ and $d$, it is possible to obtain coefficients of amplification which will always correspond to the scale of the pressures to be measured.

In this very schematic form, such a manometer could hardly be used and a perfectly horizontal tube is only possible from a theoretical point of view. In addition, the meniscus may have very varied shapes in a horizontal tube and, if the experience is to be believed, this shape depends on the diameter of the tube and the kind of liquid used. Figure 2 shows three shapes of the meniscus observed in practice. Only $(a)$ can be considered satisfactory for measurements. We believe that the maximum diameter with which the shape under consideration can be obtained may be calculated using LAPLACE's formula for the surface tension (fig, 3 ) :

$$
T=\sigma\left(1 / \mathbf{R}_{1}+1 / \mathbf{R}_{2}\right)
$$

If a meniscus having the shape $(a)$ is required in a horizontal tube, then the hydrostatic pressure at (A) should not exceed the surface tension. This results in :

$$
d . \bar{\omega}=\sigma\left(1 / \mathrm{R}_{1}+1 / \mathrm{R}_{2}\right)
$$

and with $\mathrm{R}_{1}=d / 2$ and $\mathrm{R}_{2}=\infty$ :

$$
d=\sqrt{\frac{2 \sigma}{\omega}}
$$

For water :

$$
\sigma=0.0745 \mathrm{~g} / \mathrm{cm} \text { and } \bar{\omega}=1 \mathrm{~g} / \mathrm{cm}^{3}
$$

from which : $d=0.386 \mathrm{~cm}$. 
For carbon tetrachloride,

$$
\sigma=0.0273 \mathrm{~g} / \mathrm{cm} ; \quad \sigma=1.6 \mathrm{~g} / \mathrm{cm}^{3}
$$

from which : $d=0.185 \mathrm{~cm}$.

The results obtained by using equation (3) agree with those it has been possible to observe.

Difficulties arise from the fact that the capillary tube is horizontal and these can be overcome in the following manner :

Two vessels having the same section are connected to one another by a capillary tube of diameter $d$ and are partly filled with water (fig. 4). A few drops of a liquid (aniline), which is insoluble in water, form a "plug" that travels along the tube under the action of the pressures applied. In this case, the distance between the two positions of the meniscus is:

$$
l=(8 h / 2)(\mathrm{D} / d)^{2}
$$

and the difference in pressure:

$$
p_{1}-p_{0}=\bar{\omega} .2 l /(\mathrm{D} / d)^{2}
$$

and, in this case the value of the coefficient of amplification is:

$$
A=(1 / 2 \bar{\omega})(D / d)^{2}
$$

However, this device does not operate satisfaclorily. Aniline $(w=1.02)$ is very slightly soluble in water and for this reason the "plug" disappears after a few days. But the most serious drawback, affecting the accuracy of the instrument, is the deformation of the "plug" caused by aniline sticking to the wet inside surface of the tube; to overcome these disadvantages, the aniline "plug" has been replaced by an air bubble. The latter can also block any connection between the two vessels providing that its length is at least $(3 d)$ and that the diameter of the tube does not exceed the limit established from equation (3).

With a "plug" of appreciably the same density as the liquid used, the position of the capillary tube obviously has no effect on the operation of the apparatus. But, an air bubble tends to rise and the lube connecting the two vessels must therefore be horizontal. However, the experiment showed that when the diameter of the tube satisfied equation (3) the instrument could be used whether the tube were exactly horizontal or not.

The air bubble can be formed in the capillary tube in various ways but the most convenient seems to be as follows:

When the instrument is filled with liquid and the valves have been closed, it is slightly inclined from the horizontal. Then, by using a pipette and a flexible tube, a small quantity of air is introduced so that the bubble rests near the cone of the lower valve. When suitable pressure is applied to the lower vessel, and the valves are opened slowly, the air bubble slides into the tube.

This manometer can only be used for measuring gas pressures. The best liquid to use for filling the instrument is alcohol. Water should not be used, even if it is distilled, because there is then difficulty in making the bubble slide properly in the tube. In any case, it is absolutely necessary to thoroughly clean the capillary tube before use.

Using the same principle, it is possible to construct a manometer suitable for measuring water pressures. In this case, one can even obtain a very high total coefficient of amplification by achieving the superposition of the relationship $(\mathrm{D} / d)^{2}$ and the factor $A=\bar{\omega}_{e} /\left(\bar{\omega}_{e}-\bar{\omega}_{l}\right)$ applying to two liquid manometers. A solution of this kind is shown on figure 5 .

Two $U$ tubes are connected to one another by a thin tube and filled with a liquid which is either more or less dense than water according to the arrangement indicated by the figures. It will be seen immediately that the coefficient of amplification becomes:

$$
\mathrm{A}=1 / 2 \bar{\omega}_{e}(\mathrm{D} / d)^{2} \cdot \frac{\bar{\omega}_{e}}{\bar{\omega}_{e}-\bar{\omega}_{i}}
$$

In order that it may still be possible to vary the relationship $\mathrm{D} / d$, the $\mathrm{U}$ tubes can be made with branches of different diameter.

\section{Range, accuracy and sensitivity of the instrument.}

It is possible to obtain considerable coefficients of amplification and it is therefore a natural inclination to choose high $\mathrm{D} / d$ ratios, but such high values have certain drawbacks. If a very high $\mathrm{D} / d$ ratio is taken, the range of measurement is greatly restricted unless very long tubes are used. Besides, the air bubble only becomes balanced very slowly. Fortunately, all these diffenties can be overcome if the bubble is held at zero either by using a micrometric serew which raises or lowers one of the vessels (a U tube) in the direction indicated by the difference of pressures, or by drawing of or adding a certain easily determinable quantity of liquid. The latter method seems to be the easier and more accurate because it is not necessary to have either a special manometric screw or the flexible connection between the capillary tube and the moving vessel (deformation of the flexible connection would make the measurem ments inaccurate). On the other hand, only a syringe and a calibrated pipette are required for the second method and, practically speaking, it is also very quickly completed. Both methors can be used with two liquid manometers. It is harlly necessary to point out that, for the same difference in pressure, the mobile $U$ tube will have to be raised for a liquid denser than water and vice versa.

The following results will show the degree of accuracy and sensitivity that can be expected with this type of instrument:

\section{a) ALCOHOL MANOMETER :}

$$
A=604 \pm 1.35 \%
$$

the bubble is seen to move for a difference of pressure $\delta \mathrm{h}=0.0025 \mathrm{~mm}$ of alcohol. 
b) ALCOHOL MANOMETER :

$$
A=45 \pm 0.28 \% \text {, }
$$

Wovement visible for $\delta h=0.01 \mathrm{~mm}$

c) Two Ltquid Manometer (carbon tetrachloride and water) :

$A=26.8 \pm 1.18 \%$,

Movement visible for $\delta h=0.01 \mathrm{~mm}$ of water.

Many measurements have now been made with these instruments and the results confirm their practical value.

\section{II}

The instrument which will now be discussed can only be used to measure gas pressures applied to two water surfaces. A float is used to relate the vertical movements of one of the water surfaces to an accurate geodetic level.

Float instruments can be exceptionally accurate as has been shown by Mr. Spalding with his manometer [2] and by Mr. HIckox with an evaporimeter [3].

Figure 6 illustrates the instrument we have constructed, which is described in the following paragraphs.

An $80 \mathrm{~mm}$ diameter aluminim float is placed in a $113 \mathrm{~mm}$ diameter metal cylinder. A needle on the top of the float connects with one arm of a metal cross which rests on two knife edge supports fitted to the edge of the cylinder. Two geodetic levels are carried on the cross; one of these is in the same vertical plane as the supports and is used to check that these supports are horizontal; the other, and essential one, is a precision level placed perpendicularly on the other arm of the cross. The bubble in this latter instrument follows the vertical movements of the float. If a high precision level is used, it should be possible to measure extremely small changes of level.

The normal levels are only of very restricted length but their range could be increased by applying the methods discussed in the preceding chapter.

The amplifying factor for the instrument only depends on the quality of the geodetic level and the length of the lever arm $l$. Thus, for the coefficient of amplification to be $\mathrm{A}=500$ with a level varying by $2 \mathrm{~mm}$ for $20^{\prime \prime}$, the length of the lever should be :

$$
l=2 / 500206265 / 20=41.25 \mathrm{~mm}
$$

With the first instrument constructed on this principle, it was surprising to find a much higher coefficient of amplification than expected. This was due to changes in the load experienced by the float which made the latter's draught fluctuate. It was found that the load on the float could be kept constant by replacing the fixed knife edge supports with spherical ones. The radius of curvature was calculated in the following manner (fig. 7).

$\mathrm{C}=$ the "mobile" load, i.e. the weight of the liquid in the level.

$T=$ the static load, i.e. the weight of the cross and everything mounted on it.

$\varepsilon=$ Movement of the centre of gravity.

In position $\mathrm{I}$, load on the float is calculated as :

$$
\mathrm{R}_{\mathrm{I}}=\frac{\mathrm{C} \cdot n+\mathrm{T} \cdot d}{l}
$$

After the bubble has moved (position II), the new load is :

$$
\mathrm{R}_{1 \mathrm{I}}=\frac{\mathrm{C}(n+x-\varepsilon)+\mathrm{T}(d+x)}{l+x}
$$

The condition $R_{I}=R_{I I}=$ constant requires that the length of the lever be increased or reduced in accordance with :

$$
x=\frac{\mathrm{C} \cdot l \cdot \varepsilon}{\mathrm{C}(l-n)+\mathrm{T}(l-d)}
$$

If the pressures are balanced so that the float only supports the weight of liquid in the main level, one has :

$$
l=n \quad d=0 \quad \text { and } \quad x=\frac{\mathrm{C} \cdot \varepsilon}{\mathrm{T}}
$$

whence the radius of curvature:

$$
r=\left(x / \delta^{\prime \prime}\right) .206265
$$

By changing the supports in this way, a coefficient of amplification of $446 \pm 1.2 \%$ was found and this corresponded to a value of $21.46^{\prime \prime}$ for the level. The instrument was then very accurate although this had not been the case in the first place. There was no difficulty in observing movements of the bubble for changes in level of about $0.001 \mathrm{~mm}$. It was not thought necessary to use special fittings to prevent the cross sliding on the spherical supports.

When pressure measurements are made, the cylinder is fitted with a transparent cover on which there is a nozzle for the pressure intake. The metal cylinder is connected to another receptacle.

E. Kovacic, Ljubljana, Yugoslaria 